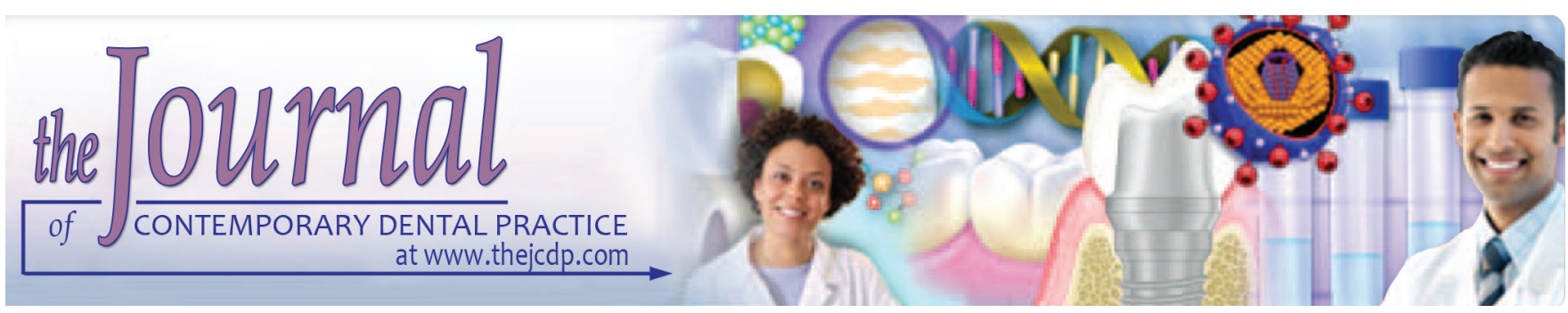

\title{
In vitro Assessment of Clasps of Cobalt-Chromium and Nickel-titanium Alloys in Removable Prosthesis
}

\author{
${ }^{1}$ Mohammed Zaheer Kola, ${ }^{2}$ Deepti Raghav, ${ }^{3}$ Prince Kumar, ${ }^{4}$ Fawaz Alqahtani \\ ${ }^{5}$ Mohammed S Murayshed, ${ }^{6}$ Tushar Vithal Bhagat
}

\begin{abstract}
Background: It has been since a long time that the use of basemetal alloys has significantly increased in the area of prosthetic science. One of the factors contributing for the increasing use of base-metal alloys is the increasing and high cost factor of noble metals. Although numerous materials have been tried since the recent past, Cobalt-Chromium (CoCr) alloys still form the most commonly used ones because of the numerous advantages they offer. Titanium alloys are also significantly being used in this field because of their high resistance strength and high corrosion resistance. Therefore, we aimed to evaluate the flexure strength and fatigue resistance of clasps made up of $\mathrm{CoCr}$ alloys and Nickel-titanium (NiTi) alloys.
\end{abstract}

Materials and methods: We evaluated the retentive forces of $\mathrm{CoCr}$ and $\mathrm{NiTi}$ clasps two different sizes engaging retentive undercuts of different depths $(0.25$ and $0.50 \mathrm{~mm})$. Mandibluar second premolar was prepared to frame the prosthesis for missing mandibular first and second molar. A total of 50 clasps were included in the study out of which 30 were NiTi clasps and $30 \mathrm{CoCr}$ clasps. We evaluated the loading of the force at the rate of half Newton $(\mathrm{N}) /$ second at the central part of the specimen until fracturing of the specimen occurred and finally measurement of the modulus of elasticity was also done. Statistical analysis was carried out; unpaired " $t$ " test was used for evaluating the level of significance.

Results: The mean load needed for CoCr clasps was 0.7450 and for NiTi clasp was $0.6140 \mathrm{Kgf}$ for producing a deflection of 0.25 $\mathrm{mm}$. As far as flexibility is concerned, more value was seen in NiTi

\footnotetext{
${ }^{1,4-6}$ Department of Prosthetic Dental Sciences, College of Dentistry, Prince Sattam Bin Abdulaziz University, Al-Kharj Kingdom of Saudi Arabia

${ }^{2,3}$ Department of Prosthodontics, Shree Bankey Bihari Dental College, Ghaziabad, Uttar Pradesh, India

Corresponding Author: Prince Kumar, Senior Lecturer Department of Prosthodontics, Shree Bankey Bihari Dental College, Ghaziabad, Uttar Pradesh, India, e-mail: princekumaronline@gmail.com
}

group than $\mathrm{CoCr}$ group. For deflecting the clasp up to $0.50 \mathrm{~mm}$, the mean load needed for $\mathrm{CoCr}$ clasps was 1.4102 and for $\mathrm{NiTi}$ clasp was $0.8260 \mathrm{Kgf}$. The results were statistically significant. While measuring the flexibility, more value $(p<0.05)$ was seen in NiTi group than in $\mathrm{CoCr}$ group. NiTi alloy clasps had mean flexural strength of $1640 \mathrm{MPa}$ and modulus of elasticity of $32 \mathrm{GPa}$.

Conclusion: For producing deflection of 0.25 and $0.50 \mathrm{~mm}$, the mean loading force was higher for NiTi alloys. Although being increasingly used these days, NiTi alloys have limited use as compared with $\mathrm{CoCr}$ alloys due to high cost of titanium and certain other limitations.

Keywords: Cobalt-chromium, Flexure strength, Nickel-titanium.

How to cite this article: Kola MZ, Raghav D, Kumar P, Alqahtani F, Murayshed MS, Bhagat TV. In vitro Assessment of Clasps of Cobalt-Chromium and Nickel-titanium Alloys in Removable Prosthesis. J Contemp Dent Pract 2016;17(3):253-257.

Source of support: Nil

Conflict of interest: None

\section{INTRODUCTION}

It has been since 1980 that the base-metal alloy's application in removable and fixed dentures in the field of prosthetic dentistry has increased. High cost factor of noble metals contributes to base metal's increasing use. Although numerous alloys have been tried and used in the past, cobalt-chromium $(\mathrm{CoCr})$ alloys are one of the best known. High strength and resistance of currently used CoCr alloys has evolved because of Elwood Haynes who did large work in this field and later identified and showed high increase in its strength by addition of molybdenum (Mo) and tungsten (W). ${ }^{1}$

Cobalt-chromium alloys have numerous qualities, including high resistance and strength, compatibility to oral tissues, and reduction of overall weight of the substance. Construction of orthopedic parts for prosthetic purpose forms the main biomedical use of $\mathrm{CoCr}$ alloys. 
Current dental use of these alloys along with $\mathrm{NiCr}$ alloys is for the fabrication of removable partial dentures. ${ }^{2-4}$

Titanium alloys also have significant use in dental prosthesis. The properties responsible are its magnificent resistance strength to corrosion and compatibility to biological tissues. Shape memory and high elastic features are some of the beneficial properties being possessed by titanium-nickel (TiNi) alloys. Titanium-nickel alloys have a unique property of rebounding from elastic deformation and remaining constant till the proportional limit. ${ }^{5-7}$ The stresses acting on the clasps of a removable partial denture should be as low as till the limit to avoid permanent deformation of the clasp. While during continuous insertion and removal of the clasp of RPD, some amount of fatigue occurs and this varies depending upon the material or alloy used. ${ }^{8}$ Therefore, we compared the strength of clasps or removable partial dentures of $\mathrm{NiTi}$ and $\mathrm{CoCr}$ alloys.

Therefore, the aim of the study was to evaluate the fatigue resistance of NiTi clasps when subjected to repeated constant deflections as compared with CoCr.

\section{MATERIALS AND METHODS}

In this in vitro study, we evaluated the retentive forces of two different clasp materials in two different sizes engaging retentive undercuts of different depths. Missing mandibular first and second molar was used for the study in which preparation of mandibular second premolar was done for surveying the complete metal crown. A total of 50 clasps were included in the study out of which 30 were $\mathrm{NiTi}$ clasps and $30 \mathrm{CoCr}$ clasps. Investment of standard half round $0.8 \mathrm{~mm}$ wax pattern was done followed by $\mathrm{CoCr}$ casting. Finishing and polishing of the final clasp was done for evaluation. Fabrication of dies of size approximately $19.2 \mathrm{~mm}^{3}$ was done followed by fabrication and adaptation of clasps was done. Casting was done using sprue former followed by flasking.

All the NiTi clasps and CoCr clasps were grouped into four groups depending upon the amount of deflection produced (Table 1).

Instron machine was used for measurement of the fatigue test. While carrying the fatigue test, two end points were assessed. Either $10^{6}$ cycles or permanent deformation, which ever occurred first, was taken as the point of measurement. Statistical analysis was carried out;

Table 1: Nickel-titanium and Cobalt-chromium clasps divided into four study groups on the basis of amount of deflection produced

\begin{tabular}{|c|c|c|c|}
\hline Groups & Clasp material & $\begin{array}{l}\text { No. of } \\
\text { specimens ( } n \text { ) }\end{array}$ & $\begin{array}{l}\text { Amount of deflection } \\
\text { produced }(\mathrm{mm})\end{array}$ \\
\hline I & $\mathrm{CoCr}$ & 15 & 0.25 \\
\hline II & $\mathrm{CoCr}$ & 15 & 0.50 \\
\hline III & $\mathrm{NiTi}$ & 15 & 0.25 \\
\hline IV & $\mathrm{NiTi}$ & 15 & 0.50 \\
\hline
\end{tabular}

unpaired " $\mathrm{t}$ " test was used for evaluating the level of significance. Digital Vernier caliper was used for assessment of the flexure strength with $\pm 0.01 \mathrm{~mm}$ accuracy. Universal testing machine was employed for carrying the bending test. Loading of the force at the rate of half Newton (N)/ second was done at the central part of the specimen until fracturing of the specimen occurred and finally measurement of the modulus of elasticity was done. ${ }^{11}$

The underlying equational formula was used for evaluating the flexural strength:

Flexural strength $=3 \mathrm{FL} / 2 \mathrm{BH}^{2} \mathrm{MPa}^{12}$

F: Max. load in N, L: Distance between the supports in $\mathrm{mm}, \mathrm{B}$; width of the specimen in $\mathrm{mm}, \mathrm{H}$ : Height of the specimen in $\mathrm{mm}$.

The underlying equational formula was used for evaluating the flexural modulus:

Flexural Modulus $=3 \mathrm{~F}_{1} \mathrm{~L}^{3} / 4 \mathrm{BH}^{3} \mathrm{~d} \mathrm{MPa}{ }^{12}$

$\mathrm{F}_{1}$ : Load in $\mathrm{N}$, d: Deflection in $\mathrm{mm}$

\section{RESULTS}

For deflecting the clasp up to $0.25 \mathrm{~mm}$, the mean load needed for CoCr clasps was 0.7450 and for NiTi clasp was $0.6140 \mathrm{Kgf}$ (Table 2, Graph 1). The results were statistically significant.

Table 2: Load needed for producing a $0.25 \mathrm{~mm}$ deflection in the clasp and the clasp's flexibility

\begin{tabular}{|c|c|c|c|c|c|}
\hline Variable & $\begin{array}{l}\text { Study } \\
\text { group }\end{array}$ & Mean & $S D$ & $\begin{array}{l}t \text { (unpaired } \\
t \text { test) }\end{array}$ & $p$-value \\
\hline \multirow{2}{*}{$\begin{array}{l}\text { Load needed } \\
\text { for producing } \\
\text { a } 0.25 \mathrm{~mm} \\
\text { deflection in } \\
\text { the clasp (Kgf) }\end{array}$} & Group I & 0.7450 & 0.0764 & 18.758 & $0.0016 \mathrm{~s}$ \\
\hline & Group III & 0.6140 & 0.0622 & & \\
\hline \multirow{2}{*}{$\begin{array}{l}\text { Clasp's } \\
\text { flexibility } \\
\text { (mm/Kgf) }\end{array}$} & Group I & 0.4020 & 0.0360 & 17.956 & $0.0024 \mathrm{~s}$ \\
\hline & Group III & 0.6024 & 0.0812 & & \\
\hline
\end{tabular}

S: Significant

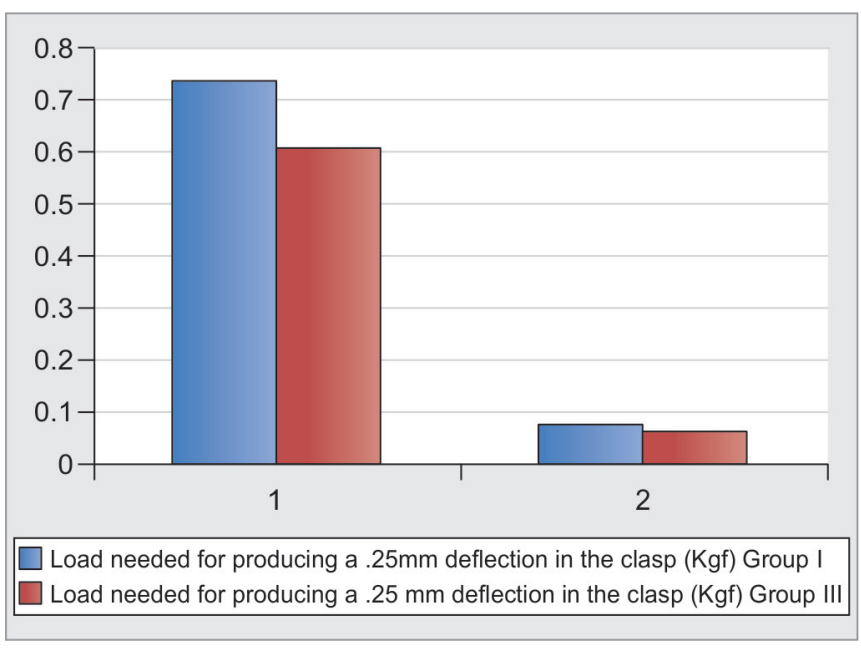

Graph 1: The mean loading force and SD for producing deflection of $0.25 \mathrm{~mm}$ in CoCr alloys (Group I) and NiTi alloys (Group III) 
As far as flexibility is concerned, more value $(p<0.05)$ was seen in NiTi group $(0.6024 \mathrm{~mm} / \mathrm{Kgf})$ than in $\mathrm{CoCr}$ $(0.4020 \mathrm{~mm} / \mathrm{Kgf})$ group (Table 2, Graph 2).

For deflecting the clasp up to $0.50 \mathrm{~mm}$, the mean load needed for CoCr clasps was 1.4102 and for NiTi clasp was $0.8260 \mathrm{Kgf}$ (Table 3, Graph 3). The results were statistically significant.

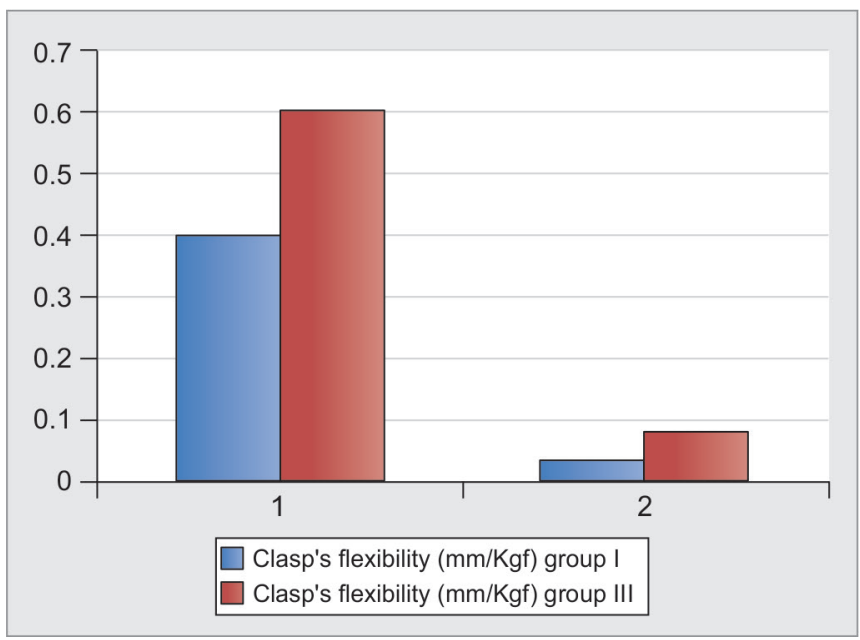

Graph 2: The mean flexibility and SD for producing deflection of $0.25 \mathrm{~mm}$ in CoCr alloys (Group I) and NiTi alloys (Group III)

Table 3: Load needed for producing a $0.50 \mathrm{~mm}$ deflection in the clasp and the clasp's flexibility

\begin{tabular}{|c|c|c|c|c|c|}
\hline Variable & $\begin{array}{l}\text { Study } \\
\text { group }\end{array}$ & Mean & $S D$ & $\begin{array}{l}t \text { (unpaired } \\
t \text { test) }\end{array}$ & $p$-value \\
\hline \multirow[b]{2}{*}{$\begin{array}{l}\text { Load needed } \\
\text { for producing } \\
\text { a } 0.50 \mathrm{~mm} \\
\text { deflection } \\
\text { in the clasp } \\
\text { (Kgf) }\end{array}$} & Group II & 1.4102 & 0.0764 & 16.465 & $0.0023 \mathrm{~S}$ \\
\hline & Group IV & 0.8260 & 0.0622 & & \\
\hline \multirow{2}{*}{$\begin{array}{l}\text { Clasp's } \\
\text { flexibility } \\
\text { (mm/Kgf) }\end{array}$} & Group II & 0.3868 & 0.0154 & 19.485 & $0.0018 \mathrm{~S}$ \\
\hline & Group IV & 0.5980 & 0.0784 & & \\
\hline
\end{tabular}

\section{S: Significant}

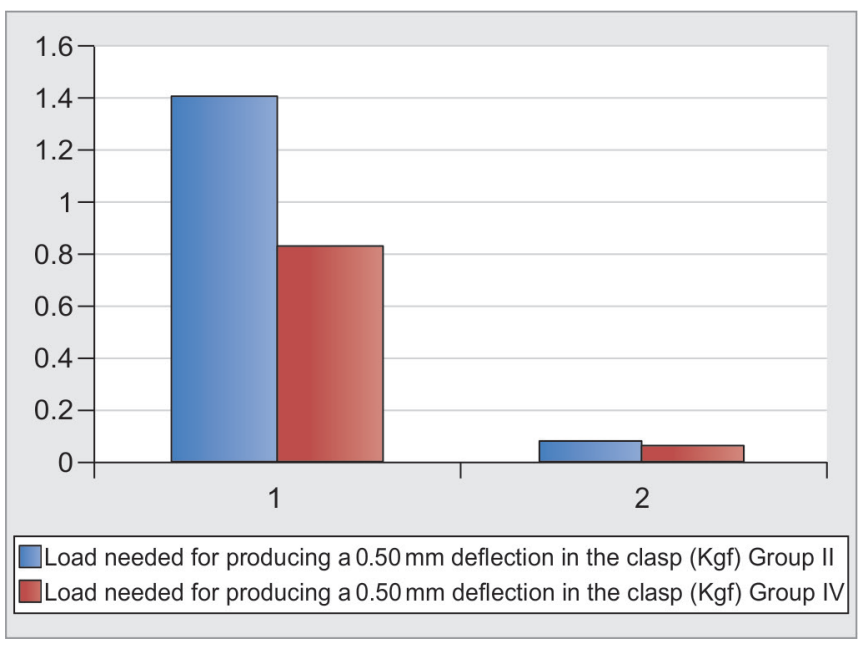

Graph 3: The mean loading force and SD for producing deflection of $0.5 \mathrm{~mm}$ in CoCr alloys (Group II) and NiTi alloys (Group IV)

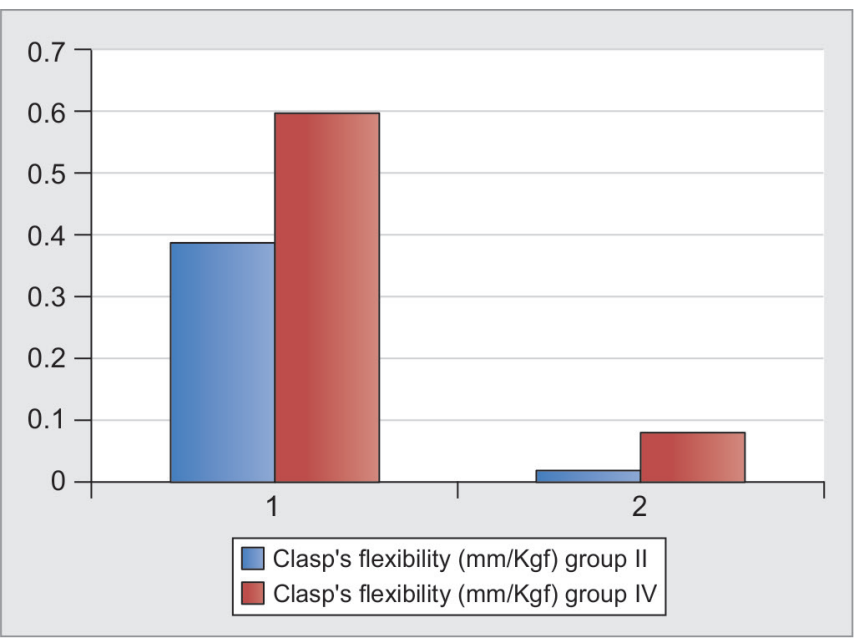

Graph 4: The mean flexibility and SD for producing deflection of $0.5 \mathrm{~mm}$ in $\mathrm{CoCr}$ alloys (Group II) and NiTi alloys (Group IV)

Table 4: Flexure strength and modulus of elasticity of nickel-chromium

\begin{tabular}{ll}
\hline Variable & Mean value \\
\hline Flexure strength & $1640 \mathrm{MPa}$ \\
Modulus of elasticity & $32 \mathrm{GPa}$ \\
\hline
\end{tabular}

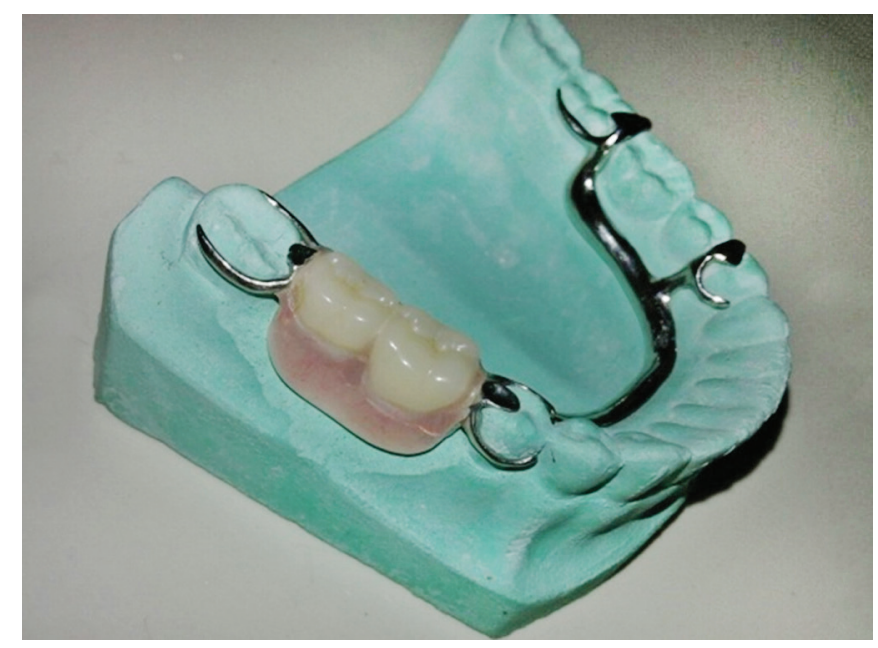

Fig. 1: Cobalt-chromium clasp

While measuring the flexibility, more value ( $\mathrm{p}$-value $<0.05)$ was seen in NiTi group $(0.5980 \mathrm{~mm} / \mathrm{Kgf})$ than in $\mathrm{CoCr}(0.3868 \mathrm{~mm} / \mathrm{Kgf})$ group (Table 3, Graph 4).

The mean flexural strength of NiTi alloy clasps is $1640 \mathrm{MPa}$ and modulus of elasticity is $32 \mathrm{GPa}$ (Table 4). Cobalt-chromium clasps are shown in Figure 1 and casting machine used in the present study is shown in Figure 2.

\section{DISCUSSION}

Adequate flexibility is a feature that removable partial denture must possess for the success and retention of prosthesis. At the same time, abutment teeth should also be relieved from undue load and forces of the clasps occurring during the functional process of the prosthesis. 


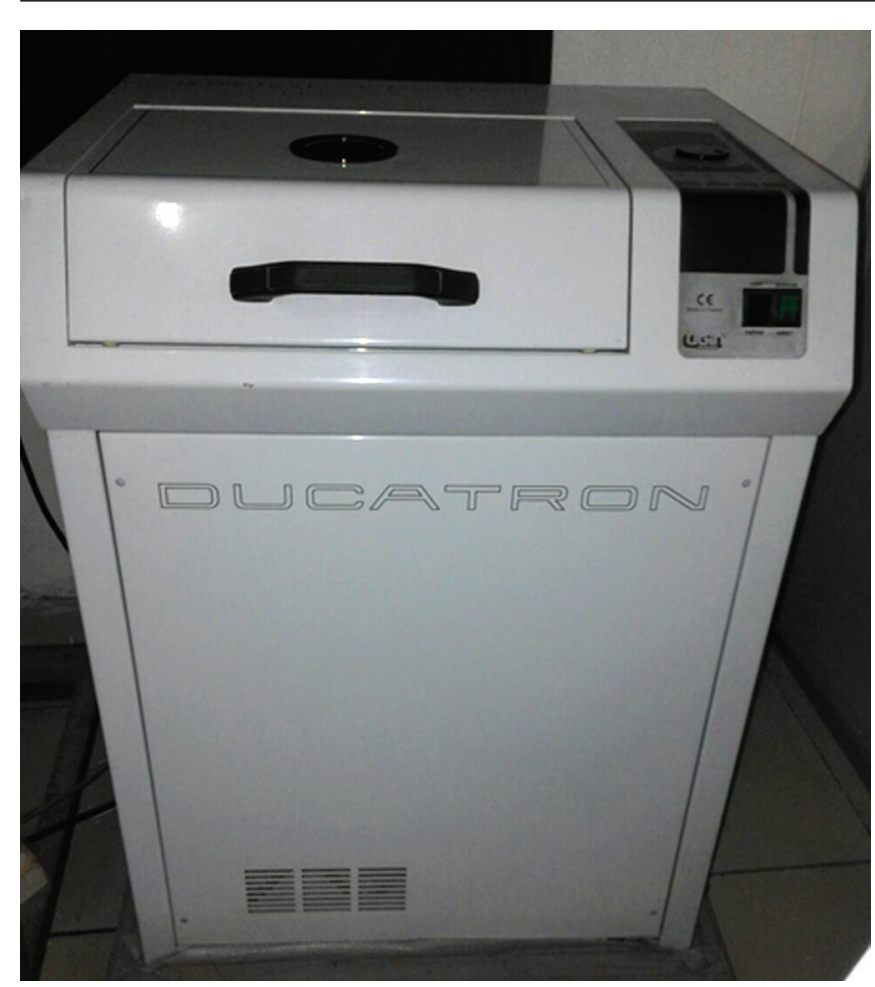

Fig. 2: Casting machine

On the other side, too flexible clasps are also not successful due to inadequate retention provided by them when used for shallow undercuts. ${ }^{9}$

In the present study, we evaluated the flexibility of the NiTi and CoCr clasps at 0.25 and $0.50 \mathrm{~mm}$ deflection by load. Selection of $0.25 \mathrm{~mm}$ of clasp was done, as they are most routinely used undercuts for CoCr clasps. For larger undercuts, patients demand placing of clasps more toward the gingival region because of esthetic reasons. As the CoCr clasps are stiffer in nature, it is difficult to use these alloy clasps for larger undercuts. ${ }^{9}$ Shape memory and good elastic characteristics are some of the useful properties possessed by NiTi alloys. The alloy has a constant stress value up to proportional limit and the value remains constant even when the alloys rebounds from elastic deformation. ${ }^{7}$

Fatigue limit of $\mathrm{CoCr}$ alloys has been reported in the range from 40 to $70 \mathrm{~K}$ psi, in various studies. ${ }^{10}$ Therefore, $10^{6}$ loading cycles were used in the recent study.

The amount of loading force that will produce a deflection of 0.25 and $0.5 \mathrm{~mm}$ is approximately equal to the retentive strength of the material for the given two undercuts. For producing equal amount of deflection (0.25 and $0.50 \mathrm{~mm}$ ) in both the groups, the mean amount of load required was significantly higher for NiTi alloys. As far as flexibility is concerned, clasps made of NiTi alloys had higher flexibility than $\mathrm{CoCr}$ alloys indicating the higher retentive strength of NiTi alloys (Tables 2 and 3). Kim et al also compared the clasp retention of NiTi clasps with conventional $\mathrm{CoCr}$ clasps and concluded that even though for all the claps included in their study, there was minimal or very less alteration seen in the values of retentive forces in the NiTi clasps as compared with the conventional clasps, even after repeated cycling procedures. $^{12}$

On evaluating the modulus of elasticity, we found that NiTi alloys (elastic modulus; $32 \mathrm{GPa}$ ) had higher flexibility than CoCr alloy (elastic modulus; 190 GPa) clasps (Table 4). We also conducted fatigue test and found that only $\mathrm{CoCr}$ alloys of $0.50 \mathrm{~mm}$ deflection showed deformation, whereas $\mathrm{CoCr}$ alloy clasps of $0.25 \mathrm{~mm}$ deflection and NiTi alloy class of 0.25 and $0.50 \mathrm{~mm}$ deflection did not produce any deformation. Savitha et al evaluated the flexural strength and fatigue resistance of $\mathrm{CoCr}$ alloys as compared with acetal resin alloys and concluded that acetal resin clasps may provide less retention than cobalt chromium based alloys. ${ }^{13}$

Because of their ability of evaluating the clinical stresses occurring, these tests of flexibility are of great significance. By applying a loading force at the rate of half Newton/second at the flexure specimen's center, measurement of the elasticity modulus and amount of maximum load that can be sustained will be done. From the above tests, it was found that mean flexural strength of NiTi was $1640 \mathrm{MPa}$ and elasticity modulus was $32 \mathrm{GPa}$. Bates ${ }^{14}$ in their study demonstrated that $0.15 \mathrm{~mm}$ deflection would be shown by a $10 \mathrm{~mm}$ long Cr-Co clasp nearby to their proportional limit. Morris et al also evaluated the permanent deformations in clasps tips and concluded that permanent deformation of the tip of the clasp by more than $0.25 \mathrm{~mm}$ may be considered as significant. $^{15}$

However, our each group had relatively small number of patients $(n=15)$. A further study with larger study groups is required for improving the quality of the clasps and the prognosis of the treatment.

\section{CONCLUSION}

Keeping in mind the shortcomings of the present study, it can be concluded that for producing deflection of 0.25 and $0.50 \mathrm{~mm}$, the mean loading force was higher for NiTi alloys. Nickel-titanium alloys are increasingly becoming popular these days but due to high cost of titanium and certain other limitations, their use is still very limited in actual practice as compared to $\mathrm{CoCr}$ alloys.

\section{REFERENCES}

1. Crook P. Corrosion of cobalt based alloys. In: Davis J, editor. Corrosion. Materials Park, OH: ASM International; 1987. p. 1. 657-700.

2. Evans EJ, Thomas IT. The in vitro toxicity of cobalt-chrome molybdenum alloy and its constituent metals. Biomaterials 1986 Jan; 7(1):25-29. 
3. Craig RG, Hanks CT. Reaction of fibroblasts to various dental casting alloys. J Oral Pathol 1988 Aug;17(7):341-347.

4. Marti A. Cobalt-base alloys used in bone surgery. Injury 2000 Dec;31 Suppl 4:18-21.

5. Castleman LS, Motzkin SM, Alicandri FP, Bonawit VL. Biocompatibility of nitinol alloy as an implant material. J Biomed Mater Res 1976 Sep;10(5):695-731.

6. Speck KM, Fraker AC. Anodic polarization behavior of TiNi and Ti-6Al-4V in simulated physiological solutions. J Dent Res 1980 Oct;59(10):1590-1595.

7. Miura F, Mogi M, Ohura Y, Hamanaka H. The super-elastic property of the Japanese NiTi alloy wire for use in orthodontics. Am J Orthod Dentofacial Orthop 1986 Jul;90(1):1-10.

8. Vallittu PK, Kokkonen M. Deflection fatigue of cobaltchromium, titanium, and gold alloy cast denture clasp. J Prosthet Dent 1995 Oct;74(4):412-419.

9. Mcgiveney GP, Carr AB. Mccracken's removable partial prosthodontics. 10th ed. Elsevier Science; 1999. p. 258-265.
10. Gapido CG, Kobayashi H, Miyakawa O, Kohno S. Fatigue resistance of cast occlusal rests using $\mathrm{CoCr}$ And $\mathrm{Ag}-\mathrm{Pd}-\mathrm{Cu}-\mathrm{Au}$ alloys. J Prosthet Dent 2003 Sep;90(3):261-269.

11. Anusavice KJ. Phillips' science of dental materials. 11th ed. St. Louis: Elsevier; 2003.

12. Kim D, Park C, Yi Y, Cho L. Comparison of cast TiNi alloy clasp retention with conventional removable partial denture clasps. J Prosthet Dent 2004 Apr;91(4):374-382.

13. Savitha PN, Lekha KP, Nadiger RK. Fatigue resistance and flexural behavior of acetal resin and chrome cobalt removable partial denture clasp: an in vitro study. Eur J Prosth 2015; 3(3):71-76.

14. Bates JF. The mechanical properties of the cobalt-chromium alloys and their relation to partial denture design. Br Dent J 1965 Nov 2;119(9):389-396.

15. Morris HF, Asgar K, Brudvik JS, Winkler S, Roberts EP. Stress-relaxation testing. Part IV: Clasp pattern dimensions and their influence on clasp behavior. J Prosthet Dent 1983 Sep;50(3):319-326. 